Buana Sains Vol 17 No 1: 111 - 114

\title{
POLA WILLINGNES TO PAY (WTP) KOMODITI TAHU DAN DAGING MASYARAKAT KOTA MALANG
}

\author{
Umi Rofiatin $^{1}$ dan Taufik Iskandar ${ }^{2}$ \\ ${ }^{1}$ Fakultas Pertanian Universitas Tribhuwana Tunggadewi \\ ${ }^{2}$ Fakultas Teknik Universitas Tribhuwana Tunggadewi
}

\begin{abstract}
Soybeans and meat are the most strategic food commodities and are very risky if it is fully entrusted to the mechanism of the free market. The point is, soy and meat commodities have a very central role in national food policy channels. One of the agricultural ministry targets for 2010 - 2014 is to increase food diversification, especially to reduce rice and wheat consumption. During 2010 - 2014, rice consumption is targeted to fall by $1.5 \%$ per year and balanced by increasing in consumption of tubers, animal foods, fruits and vegetables. On the other side, it is also strived to achieve a diverse, nutritious, balanced and safe food consumption pattern as reflected by the increase of Expected Food Pattern (PPH) scores from 86.4 in 2010 to 93.3 in 2014. This study aimed to determine the characteristics of the community in taking decision to buy food products from both tofu and meat sources and to analyze the key factors of consumer's willingness to buy tofu and meat by using multiple linear regression methods. The results of the study showedthat the characteristics of respondents in the research that affected the gender of respondents were women because married women were the decision makers in terms of household needs. The factors that affected the willingness of consumers to pay tofu were: taste, price and size. Meanwhile, thefactors that affected consumers' willingness to pay for meat were price and shape.
\end{abstract}

Kata Kunci: WTP, tofu, meat

\section{Pendahuluan}

Berbagai ragam produk pangan yang dikenal masyarakat Indonesia saat ini, telah jauh berbeda dengan apa yang dikenal pada kurun waktu 10-2- tahun yang lalu. Era Agroindustri yang ditandai dengan munculnya produsen dan industry pangan memberikan banyak kontribusi pada ragam pangan yang dikenal masyarakat. Pergeseran orientasi dan pandangan serta pengetahuan masyarakat yang semakin maju akan mendorong masyarakat untuk mengkonsumsi berbagai produk alternatif pangan diantaranya tahu dan daging. Penerapan program diversifikasi pangan yang baik dan dapat dijamin keberhasilan pelaksanaannya diperlukan usaha untuk merubah dan mengarahkan pola konsumsi pangan masyarakat kearah penganekaragaman pangan. Tahu dan daging sebagai produk pangan yang diharapkan akan dapat menjadi alternative diversifikasi pangan. Dengan mengetahui dan menganalisa karakteristik konsumen tahu dan daging dan faktor kunci yang menjadikan kesediaan konsumen melakukanpembelian tahu dan daging, diharapkan pemerintah dapat 
menentukan trend dan tepat dalam mengambil kebijakan dalam hal diversifikasi pangan.

Tujuan Penelitian : Mempelajari dan merumuskan karakteristik konsumen tahu dan daging dan faktor kunci yang menjadikan kesediaan konsumen melakukan pembelian tahu dan daging di wilayah kota Malang dan menggambarkan implikasi karakteristik konsumen tahu dan daging dan faktor kunci yang menjadikan kesediaan konsumen melakukan pembelian tahu dan daging bagi arah penelitian, pendekatan dan arah kebijakan strategis penganekaragaman pangan.

\section{Metode Penelitian}

Populasi dalam penelitian ini adalah masyarakat di 5 kecamatan yaitu kecamatan Kedung kandang, kecamatan Sukun, kecamatan Blimbing, kecamatan Lowokwaru dan kecamatan Klojen. Pemilihan responden penelitian dilakukan dengan menggunakan Simple Random Sampling, yang dimana jumlah sampel yang ditentukan sebesar 50 sampel dengan pertimbangan tingkat kesalahan 5\%. Dari 50 sampel ini akan distribusikan pada desa di setiap kecamatan. Jumlah responden diperkirakan 250 orang. Data yang terkumpul akan dianalisis dengan menggunakan teknik analisis regresion (regresi linier berganda). Model Regresi berganda yang dituliskan sebagai berikut:

:

$\mathrm{Y}=\underset{+\mathrm{U}}{\beta 0+\beta 1 \chi 1+\beta 2 \chi^{2}+\beta 3 \chi^{3}+\beta \mathrm{n} \chi \mathrm{n}}$

Keterangan : Fungsi tersebut menerangkan hubungan antara variabel bebas (X) dan variabel terikat $(\mathrm{Y})$, dimana : y : Pembelian Tahu dan Daging; x1 : Rasa; x2 : Harga; x3 :Ukuran ; $x 4$ : Bentuk

\section{Hasil dan Pembahasan}

Responden pada penelitian ini sebagian besar berjenis kelamin perempuan $(85,60 \%)$. Hal ini dikarenakan terdapat kecenderungan terhadap peran perempuan dalam proses pengambilan keputusan rumah tangga terkait dengan pembelian kebutuhan pokok seperti tahu dan daging.

Karakteristik Responden meliputi : Usia responden pada penelitian ini berkisar 20 tahun sampai 65 tahun. Usia seseorang diasumsikan dapat mempengaruhi keputusan untuk melakukan keputusan dalam kesediaan membeli tahu maupun daging. Semakin tua usia responden akan mempengaruhi kemauan dalam mengambil keputusan.

Menurut tingkat pendidikan, dari 64 orang sebagian besar berpendidikan SLTA yaitu sebesar 25,6 persen, berpendidikan SLTA atau sederajat, sedangkan yang paling lecil adalah tidak tamat SD terdapat 10 orang atau 4 persen, kemudian responden dengan tingkat pendidikan SD atau tamat SD adalah 25 orang atau $10 \%$, responden tingkat pendidikan SLTP 45 orang atau $18 \%$, sedangkan 59 orang dengan tingkat pendidikan akademi atau 23, 6 persen dan responden dengan tingkat pendidikan perguruan tinggi adalah 47 orang atau 18,8 persen.

Berdasarkan tingkat rata - rata pendapatan responden tiap bulan, kebanyakan responden mempunyai pendapatan sebesar Rp. 750.000,- sampai Rp. 1.250.000,- yaitu 85 orang atau 34 persen dan rata - rata pendapatan terendah pada pendapatan R. 1.250 .000 yaitu 25 orang responden atau $10 \%$. Pendapatan rata - rata Rp. 250.000,sampai Rp. 750.00075 orang atau 30 persen, sebaran responden dengan pendapatan Rp. $\geq 1.750 .000$,- 65 orang atau 26 persen. Dan tidak terdapat pada 
masyarakat yang mempunyai pendapatan Rp dibawah 250.000.

\section{Analisis Tingkat Kesediaan Membayar Konsumen Tahu}

Analisis WTP ini dilakukan untuk mengetahui berapa nilai maksimum yang mereka sediakan untuk mereka keluarkan terhadap komoditi tahu. Responden berjumlah 250 orang dan 234 orang atau 94 persen bersedia meembayar untuk membeli tahu. Sisanya 15 orang atau 6 persen tidak bersedia untuk membayar untuk membeli tahu. Alasan responden bersedia membayar dalam melakukan pembelian komoditi tahu adalah karena, mudah untuk mengolah, harga relatif murah dan menyehatkan. Sedangkan alasan responden yang tidak bersedia untuk membayar komoditi tahu 15 orang atau 6 persen adalah karena tahu bukan merupakan makanan favorit karena responden menyukai komoditi yang berbahan sama tetapi berbeda jenisnya seperti tempe dan karena ada pantangan untuk tidak boleh mengkonsumsi komoditi tahu terdapat riwayat kesehatan untuk tidak mengkonsumsi tahu.

Faktor - faktor yang mempengarubi pada kesediaan konsumen dalam melakukan pembayaran pada komoditi tabu

Variabel tersebut adalah Rasa, harga dan Bentuk. Tahu memang mempunyai rasa khas yang apabila dikonsumsi oleh konsumen bagi yang menyukai komoditi ini akan membikin ketagihan. Harga yang relatif masih terjangkau oleh masyarakat merupakan salah satu pilihan bagi konsumen untuk melakukan keputusan bersedia untuk melakukan pembelian pada tahu. Kemampuan bayar yang diberikan oleh konsumen berkisar antara Rp. 3000,- / potong untuk jenis tahun kotak biasa, sedangkan tahu Sutra harga kesediaan yang harus dibayarkan adalah Rp.3500,- dan tahu bulat Rp. 4000,-. Bentuk merupakan salah satu referensi bagi konsumen dalam pengambilan keputusan (Tabel 1)

Tabel 1. Faktor - faktor yang mempengaruhi pada kesediaan konsumen dalam melakukan pembayaran pada komoditi tahu

\begin{tabular}{llllll}
\hline & \multicolumn{1}{c}{ Coefficients } & Standard Error & T Stat & Signifikasi \\
\hline Intercept & 3.9778 & 2.0972 & 1.8967 & & \\
Rasa & 0.0611 & 0.0238 & 2.5670 & $*$ & \\
Harga & 2.5809 & 0.3850 & 6.7031 & $*)$ & \\
Bentuk & 0.3463 & 0.0709 & 4.8841 & $*)$ & \\
Ukuran & -0.5651 & 0.1649 & -3.4261 & & \\
\hline
\end{tabular}

Keterangan : $\left.\mathrm{R}=0.8589 / \mathrm{R}^{2}=0.6342,{ }^{*}\right)$ Nyata pada $\alpha=5 \%$

Kesediaan Membayar Konsumen pada Komoditi Daging

Analisis WTP ini dilakukan untuk mengetahui berapa nilai maksimum yang mereka sediakan untuk mereka keluarkan terhadap komoditi tahu. Responden berjumlah 250 orang dan 20 orang atau $8 \%$ persen bersedia membayar untuk membeli daging. Sisanya 230 orang atau 92 persen tidak bersedia untuk membayar untuk membeli tahu.

Responden yang bersedia melakukan pembayaran terhadap komoditi daging sangat rendah yaitu 20 orang atau 8 persen dan yang tidak bersedia membayar pada tingkat maksimum 230 orang atau 92 persen. Harga Rp. 121.000,- perkilo untuk daging sapi dan Rp. 35.000,- untuk daging ayam. Alasan Ketidak bersediaan responden 
untuk membayar daging ( memutuskan membeli daging) adalah daging bukan merupakan kebutuhan pokok sehingga apabila harga naik maka tidak akan mempengaruhi keinginan untuk melakukan pembelian. Persepsi konsumen yang takut dampak dengan mengkonsumsi daging bagi kesehatan. Dampak kesehatan yang diakibatkan adalah timbulnya berbagai penyakit. Sedangkan alasan bersediaanya responden membayar daging adalah
Konsumen tidak setiap hari mengkonsumsi daging sifatnya jarang, adanya anak yang menyukai daging, daging menyehatkan.

Faketor - faktor yang mempengarubi kesediaan konsumen membayar daging

Daging merupakan salah satu komoditas dikonsumsi oleh masyarakat, dengan rasa yang enak daging merupakan salah satu pilihan bagi keluarga yang dijadikan sebagai lauk pauk pada keluarga.

Tabel 4. Faktor yang mempengaruhi kesediaan konsumen membayar daging

\begin{tabular}{lclll}
\hline & Coefficients & Standard Error & T Stat & Signifikasi \\
\hline Intercept & 6.2299 & 1.9889 & 3.1324 & \\
Rasa & -0.2668 & 0.3652 & -0.7307 & \\
Harga & -0.6322 & 0.0672 & -9.4011 & $*)$ \\
Ukuran & 0.0634 & 0.0676 & 0.9377 & \\
Bentuk & 0.0041 & 0.0010 & 4.1737 & $*$ \\
\hline
\end{tabular}

Keterangan : $\left.\mathrm{R}=0.6375 / \mathrm{R}^{2}=0.3889 ;{ }^{*}\right)$ Nyata pada $\alpha=5 \%$

Hasil regresi menunjukkan bahwa Harga yang tinggi akan menurunkan kesediaan membayar daging, karena dengan harga yang tinggi konsumsi masyarakat akan cenderung turun. Bentuk daging mempengaruhi kesediaan konsumen dalam memutuskan untuk membeli daging. Harga maksimum yang dibayar oleh konsumen adalah Rp. 121.000,- / Kg. Dan harga daging ayam Rp. 35.000,/ Kg.

\section{Kesimpulan dan Saran}

Karakteristik responden dalam penelitian yang mempengaruhi adalah jenis kelamin responden yaitu perempuan karena perempuan yang sudah berumah tangga merupakan faktor penentu pembuat keputusan dalam hal pemenuhan kebutuhan rumah tangga; Faktor yang mempengaruhi dari kesediaan konsumen dalam membayar tahu adalah: rasa, harga dan ukuran ; Faktor yang mempengaruhi kesediaan konsumen dalam membayar daging adalah Harga dan Bentuk

\section{DAFTAR PUSTAKA}

Ali Saadi et al,2009. Analysis of Factors Affecting Agricultural Organic Products Difusion Among Consumers: Perception of Extension Workers. World Applied Sciences Journal 6 (3): 331 - 338. Iran

Agustina Shinta, 2011. Manajemen Pemasaran. Fakultas Pertanian Universitas Brawijaya. Malang.

John C. Whitehead, Thomas J.Hoban, and William B.Clifford, 2009. Willingnes to Pay For Agricultural Research and Extension Programs. Journal of Agricultural and Applied Economics 33.1 :91-101

Ratih Fadlilah Awaliyah,2010. Analisis pengaruh persepsi konsumen dan bonus dalam kemasan terhadap keputusan pembelian. Thesis fakultas ekonomi dan bisnis. Universitas islam negeri syarif hidayatullah. Jakarta. 